\title{
Zonality, Interzonality, Height Belts and Extrazonality in the Vegetation Structure (Some Methodological Aspects)
}

\author{
Alexander P. Sizykh \\ Siberian Institute of Plant Physiology and Biochemistry SB RAS, Irkutsk, Russia \\ Email: alexander.sizykh@gmail.com \\ Received 7 March 2016; accepted 21 March 2016; published 25 March 2016 \\ Copyright (C) 2016 by author and OALib. \\ This work is licensed under the Creative Commons Attribution International License (CC BY). \\ http://creativecommons.org/licenses/by/4.0/

(c) (†) Open Access

\section{Abstract}

The problem of state assessment and change forecast in the whole ecosystems and in the vegetation structure in particular makes a basis of modern biogeographical, geobotanical, biocenological and ecological studies. The main task is to study spatial-temporal self-organization of phytocenoses under different physical-geographic conditions reflecting practically all changes in the environment for a concrete time period. With such an approach, a phytocenosis is considered as a system, which forms and develops as united one and forms interdependent links with systems of other hierarchical level, with ecotopes conditions, and with territorial attachment in general. As methods for definition of long-term trends in the dynamics of vegetation cover structure are mainly at different stage of development, it causes to researchers a series of problems from choice of concept basis to notions and terms establishment for the revealed processes and states of the plants and of the ecosystem in general. Solution of such tasks inevitably results in the necessity to correct the existing understanding of processes occurring in vegetation and allows outlining a direction of their development in the system of natural factors of any territory. This results in the appearing of basis for determination of age, site and role of current states of phytocenoses in successional systems. It is necessary for this to reveal the peculiarities of phytocenoses composition and combining connected with natural dynamics of environmental factors, environmental factors with impact of the anthropogenic factors as well. To study structural-dynamical organization of phytocenoses under transitional different environmental conditions of a definite genesis and territorial attachment it's necessary to use the definitions of "ecotones" and "paragenese" (an object) as phytocenotically separate natural phenomena characterizing the structural peculiarities of cenoses appropriate for interzonal, interbeltic, intrazonal and intrabeltic environmental conditions as well.

\section{Keywords}

Vegetation, Zonality, Interzonality, Height Belts and Extrazonality, Physical-Geographic Conditions 


\section{Subject Areas: Biogeography}

\section{Introduction}

On the background of global climate dynamics, a particular importance of vegetation cover changes arises [1] [2] with revealing of critical levels of the state of natural systems in the whole [3] [4] and of phytocenoses in particular on the background of repeatability of ecological processes during a definite time period. Such forecasts require an informational basis concerning the regularities of structural-dynamic organization of vegetation. On this basis models of vegetation successions are established, and those of successions related to the character of leading landscapes forming factors just result in the succession of vegetation as an ecosystem processing. In the system of geographical zonality (by proportion of heat and humidity, direct and back radiation), the latitudinal zonality is primary, and height belts are secondary and it emphasizes in part the specifics of a natural zone. Due to changes in solar radiation at the boundary of transition of atmospheric humidification (from oceans deeply into the continents), the latitudinal zonality in mountain systems is substituted by height belts, which are situated in a definite belt of solar radiation [5].

\section{Review of Knowledge}

Phytocenology and geobotany have accumulated a considerable knowledge amount promoting the solution of a problem of self-organization of vegetation as a system due to some postulates: 1) vegetation studies cannot be based on consideration of its separate components; 2) it is necessary to reveal "linking" mechanisms of self-organization of vegetation cover of different hierarchical levels in a concrete region; 3) it is necessary to make synthesis of different knowledge and data into a united system of research methods of spatial-temporal organization of vegetation. This is especially important for the territories of contact of natural zones contact (height belts in mountains) and under the conditions of extrazonality within a zonal vegetation type.

The essence of systematic approach in the studies is use of attendant information for analysis of state, classification and forecasting of natural systems of any structure and hierarchy, especially for the zones at contact of different environments. A method for diagnosis of state of adjacent systems of integration areas is necessary as it allows obtaining information "concerning assessment of adjacent ecosystems' state, as these are zones very rich in information" [6]. However, the organization of object (phenomenon) monitoring in time and space, the assessment of the state of the ecosystem in the whole and of vegetation in particular requires a comprehensive analysis of its structure and of its modern state, of appearing history, of dynamics and development under concrete physicalgeographical conditions. The contrast pattern of environmental conditions where a phytocenosis is formed can be revealed by establishment of a network of model sites, by their amount and, this is an important factor, by frequent descriptions of phytocenoses state in a concrete time period (by ten-day periods, by seasons of vegetational periods during different climatic years, etc.). The vegetation structure, especially in transitional zones, is a determining factor in the correction of sites, time and frequency for descriptions of cenoses. The revealing of structuraldynamic changes of phytocenoses under different physical-geographical conditions under definite climatic conditions generating a concrete vegetation type [7] allows to judge about the range of such changes in the structure of phytocenoses in space and time.

Many researchers paid much attention in their studies to problems of zonality and height belts in vegetation structure on some aspects of these problems concerning different territories in different time [8]-[31]. There are rather many papers where several notions are analyzed, such as zonality, height belts, and rare extrazonality in characteristics of structural-dynamical organization of vegetation cover at territories different by physical-geographical conditions. Let us present due to this fact approaches and studies results which we consider as main ones.

For example, while classifying steppes for demarcation, Ye. M. Lavrenko [32] understood zonal vegetation as plakors phytocenoses with heterogenous composition. He performed demarcation of the steppe zone into zonal-provincial areas. I.e., the steppes zone was considered here as a separate natural phenomenon with characteristic regional heterogeneities of the vegetation structure. Dealing with problem of zonation of USSR environment, L. S. Berg [8] understood environmental zones as areas of predominant development of the same landscapes. He 
revealed tundra, forest, forest-steppe, semidesert, desert and subtropical zones. The dynamics are manifested in the tendency of phytocenoses of different seriation degree to transit into aboriginal state meeting zonal norm, where environmental zones are differentiated by criteria of heat and humidity provision [33].

There are as well forest-steppe cenoses, which are separated from taiga by subtaiga (subzone). Such cenoses are found out, e.g., at the boundary of south-taiga subzone of Pre-Angara. In the subtaiga, the forests of taiga appearance occupying zonal sites are distributed in a considerable area. Although subtaiga forests have many common features with forest-steppe ones in the form of dominating of meadow-forest mesophytes, the species diversity in forest-steppe is greater, and the role of small-leaf tree species as indicator of forest-steppe zonality is more considerable. The plakors subtaiga is represented by mixed dark-coniferous-small-leaf forests. The zonalsubzonal peculiarities of vegetation structure are clearly found out. Under mountain conditions, where belts are manifested, formation of mountain-forest-steppe belt is found out. This is especially characteristic, e.g., for mountains in Tuva Republic, Trans-Baikal, Mongolia. As for Pre-Baikalian and Trans-Baikalian steppes-these are separate "steppe islands" formed in Pleistocene due to permafrost expansion [25]. Dark-coniferous forests dominated earlier in the Angara River basin, and after fires, dominant positions in timber stand were transferred to pine as more adapted to dry conditions of habitats tree species with formation of steppe cenoses as well. The presence of steppe cenoses here was due to climatic and edaphic factors. M.G. Popov [34] stated in his studies that due to its environmental forming features, a forest of any kind, composition or structure would cover earlier or later any steppe territories, at least as park plantations but with conservation of steppe pockets among taiga due to increase of climate dryness in the beginning of the century.

There are in all the Siberia in taiga zone some steppe sites as "islands" of different areas, often in intermountain troughs (depressions), in rivers valleys, on steep slope reaching sometimes tundra boundary. They do not form any natural zone from spatial viewpoint, as, e.g., forest-steppe one. From north to south, the proportion between taiga and steppe changes in the favour of the latter. The occurrence of stepped site in the taiga zone decreases from east to west. In difference with zonal forest steppes and subzonal (plakor) subtaiga, as well as with forest-steppe belt and belt of low-mountain subtaiga [12], the "island" steppes, from our viewpoint, are a sort of a stage of dynamic of any concrete type of zonal vegetation or mountain belt with its specifics and development history. There is also in the vegetation cover structure such phenomenon as "tundra-steppe" reflecting the ambiguity of tundra development as of zonal type of vegetation [35]. The importance of microecological conditions for the growing of trees species in the ecotone "forest-tundra" manifests modern trends of formation of high-mountain ecotones. In the latter case, there are some rather ambiguous conclusions about the role of ecological conditions in the growth of trees species at the upper forest boundary on Taymyr Peninsula. It is underlined in particular that favourable hydrological conditions of soil for trees growth in the ecotone "forest-tundra" form always, independently on trends of climate changes (cooling or warming). Under mountain conditions, the interaction of taiga with steppes determines formation of a belt in the vegetation structure. S. V. Kakareka [36] determined the site of contact of forest and steppes for Tuva Republic mountains as a form of combination of meadow steppes and park forests linked by dynamic (successional) transitions, often of combination of steppes and dry forests without expressed transitions. Comparing the similar situation of steppes development in Buryat Republic, Kansk Depression, Khangay mountains, he came to a conclusion about increase of territories occupied by forests resulting in different forms of forest and steppes contact. Age structure of timber stands forming in the contact with steppes and forms of transition of forest into steppe reflected a forest-steppe form of development. While analyzing local forms of relief stipulating peculiarities of forests and steppes interactions, a characteristic forest-steppe form of vegetation cover development was revealed as a transitional part between steppe and taiga belts.

N. B. Yermakov [37] studying vegetation structure of middle current of the Katun' River (mountain Altay) supposed that under the conditions of zonality (or height belts) topological differences of climatic factors stipulating formation of forest-steppe landscapes manifest formation of a system of steppe and forest cenoses on the base of orographic differences of the relief. He revealed a forest belt with two subbelts: cedar-larch and larchcedar. Here, the division into belts was manifested not only on the level of cenoses composition, but also in the spatial structure of vegetation (mountain-forest-steppe and mountain-steppe belts). Under the conditions of height belts in the region (mountain Altay), such differentiation of the vegetation cover is rather regular. Compiling the results of studies of South Siberia steppes (in particular, Tuva Republic and South-East Altay, Altay-Sayans highland), he came to a conclusion that while revealing steppe, forest steppe and high-mountain belts, subbbelts could be revealed: deserted-steppe and high-mountain steppe ones. A good development of height belts in mountain Altay was outlined in the paper by G. N. Ogureeva [38]. 
As mountain relief impacts climatic and natural peculiarities of any territory, it is reflected in the complex distribution of vegetation cover in the whole. E.g., the Baikal Region is characterized by mutual penetration of taiga and steppe phytocenoses, when taiga along the slopes (especially "shadowed" ones) and mountain crests expands up to zonal mountain forest-steppes and steppes of North Eurasia (southern boundary of Buryat Republic), while the steppes expand far northward in depressions bottoms and represent "steppe islands" in intermountain valleys among zonal mountain taiga (it is in particular characteristic for Pre-Baikal and Trans-Baikal). Such "steppe islands" formed due to depressional climatic effect [39] are considered in scientific papers as an integral part of a forest zone. E.g., Barguzin and Uda steppes are related to Central Siberian province of Eurasian coniferous forests area while Selenga steppes are included in Dauria-Mongolia province of Eurasian steppe area. Sites of "stepped slopes" are characteristic for the whole Baikal region from the Upper Angara River basin and Vitim taiga to mountain slope of Baikal'sky, Primorsky, Barguzin Ridges, Tunka mountain system and central part of western coast of Lake Baikal (Pre-Ol'khon). Under the conditions of Tunka (South-Western Pre-Baikal), Barguzin (North-Eastern Pre-Baikal) Depressions and Pre-Ol'khon midlands (western coast of Lake Baikal), the forests are in direct contact with steppe (extrazonal) cenoses and are formed on the soils of the same types under the same landscape-climatic conditions of the region. They are called as well "uburs", "yelakans" and "maryans". It is appropriate here to refer to the opinion of I.N. Safronova [40] based on the statement that each latitudinal zone is characterized by dominance of a concrete vegetation type referring to fundamental definitions of zonality in the vegetation structure presented in the paper by Ye. M. Lavrenko [18]. "Zonal type" can not to be expressed under some regional conditions [40], but different "ecological variations" can be extended. It this case, this definition is very closely correlated, in our opinion, with "extrazonality" in the structural-dynamic organization of vegetation. Latitudinal zonality is primary by proportion of heat and humidity, and height belts are secondary, and under mountain conditions, the latitudinal zonality increases the specifics of height belts organization, but in a definite belt of solar radiation, e.g., mountain systems of the Baikal region, in particular, of South Buryatia and TransBaikal, are in "steppe" and "forest-steppe" radiation belts [5] under the conditions of insular and permanent permafrost. This is reflected in spatial-dynamic organization of the vegetation in a whole.

At present, there are many data of different kind concerning the dynamics of forest upper boundary for different mountain systems [17] [20] [27]. In their recent studies, the authors [41] presents data on vegetation dynamics of Kola Peninsula in the cenoses of ecotones "tundra-taiga" characterizing changes in cenoses structure with trend to increase of canopy of birch crooked forests and concretion of undershrub vegetation in tundras on the background of climatic changes, in particular, increase of air temperature and of precipitations amount for 1986-2005. It was stated that environmental condition improvement forwarded the expansion of thermophyte species northward. Some researchers, having studied the dynamics of tree vegetation upper boundary at Pre-Polar Ural for last 120, noticed the expansion of trees species into mountain tundra [28]. This was confirmed by comparative analysis of photographs of different years of survey. However, the authors [28] took into account that expansion of trees species into mountain tundra is unequal for the slopes of different expositions and depended on local growth condition, mainly, on snow cover height and soils temperature during winter period as rising of forest upper boundary occurred just at sites with abundant snow amount and started in the end of XVIII century.

Spatial and vertical stratigraphies of vegetation under the conditions of zonality and height belts are regular and represent concrete systems with a definite set of environmental factors stipulating them. There is no doubt in this fact. The doubt appears when the same notion characterizes different cenoses of different environments. E.g., geobotany and biogeography use such definitions of phytocenoses under transitional environmental conditions of different size and territorial relation as "boundary zones", "tension zones", "strugle zones”, as well as such cenoses as "rim", "membrane”, "buffer", "border" and "forest edge" [42] [43] ones. This has more particular and indefinite classification sense at typification of environmental contact cenoses. The most often is observed at regional-topological level of vegetation organization. Consequently, at finding out and determination of object-phenomenon, it is necessary to take into account in every way the peculiarities of structure, dynamics and genesis of the environment stipulating typological-dynamical essence of any phytocenosis. While classifying cenoses, it is necessary in this case to take into account all the specifics of the territory (including dynamical peculiarities and vegetation genesis) to avoid uncertainties in understanding of the fact which cenosis is related to which vegetation type in each concrete case.

\section{Discussion}

The analysis of the material presented above confirms that is necessary to make more concrete the sense of the 
terms: what are "steppe”, “forest-steppe”, “subtaiga” under the conditions of zonality and of height belts and, which is principal, under those of extrazonality. We have to take into account that "steppes” and "forest-steppes” are often outlined within taiga zone or a forest belt. These natural phenomena denote quite concrete environments reflecting different physical-geographical conditions. Probably, it is necessary in this case to present the informational essence of such definitions in more detail.

The methodological base for studies of the peculiarities of vegetation structural-dynamic organization at the contact site of different environments during many decades is such definition as “ecotone” [44]-[47]. Up to present time, this term is used for the description of any phytocenosis of transitional type from forest edge [36] [43] to zonal type of cenoses [31] [48]. Due to this fact, we have to state that there is no unique approach to the determination of sense of such notion as "ecotone" while characterizing the structure of vegetation cover of contrast (transitional) environmental conditions. This is partly due to an insufficient development of criteria determining the range of this notion. As a result, we have a term inversion, when different by their genesis and structure cenoses reflecting quite different physical-geographical conditions of their formation at a concrete territory become objects of the same range in vegetation typification and classification.

We understand ecotones as phytocenoses at transitional territories between environmental zones (between zonal vegetation types to wide extent of this notion), between height belts at such contact sites as "forest-subgoltsy belt”, "forest-mountain tundra” and phytocenoses at transitional territories between polydominant darkconiferous-light-coniferous forests and dark-coniferous taiga in a height gradient. Ecotones in the vegetation structures are phytocenoses reflecting the character of environmental zones (or height belts) relations. Considerable change in the proportions of heat and humidity results in change of boundaries of environmental zones (or of height belts) as of definite environments with spatial "widening” or "narrowing” (at definite scenarios of environmental conditions changes) in ecotones as interzonal (or interbeltic) formations.

To characterize the contrasts (heterogeneities) of the structure of natural systems of different environments at concrete territories, such terms as "paragenese" is being used as well for many years [15] [49]-[57]. As for use of the term "paragenese" to characterize the heterogeneity of vegetation structure, it has up to present time mainly theoretical sense, there are very few papers in this field of phytocenology, geobotany and biogeography [58].

In our opinion, the term "paragenese” characterizing "an object” is very important for finding out and for characterization of the heterogeneity of phytocenoses structure within environmental zones (vegetation types determining an environmental zone) described in scientific papers as extrazonal cenoses (e.g., "insular steppes” within a taiga zone). We do think that paragenese (an object) in the vegetation structure represents cenoses, which reflects structural-dynamical peculiarities of ecotops within environmental zones (or height belts). These systems of spatially-adjacent regional-topologically (or typologically) different phytocenoses are linked by common origin at any territory for a definite time period.

\section{Conclusion}

The above cited principal problems of classification of environmental contact phytocenoses (under transitional environmental conditions) require solutions, and studies in this field are important both from scientific and from practical viewpoints as they are allowed to assess the state of natural zones (and height belts) and to forecast changes in the structure of their vegetation cover on the background of climate dynamics in more founded way. We believe that to study structural-dynamical organization of phytocenoses under transitional environmental conditions of a definite genesis and territorial attachment, it is necessary to use the definitions of "ecotones" and "paragenese” (object) as phytocenotically separate natural phenomena characterizing the structural peculiarities of cenoses appropriate for interzonal, interbeltic, intrazonal and intrabeltic environmental heterogeneities of concrete physical-geographical conditions of any territory. Finding of modern vector of phytocenoses formation as of "ecotones" and of "paragenese” (object) allows determining in detail characteristic dynamical trends in the vegetation genesis at wide territories in time and space.

\section{References}

[1] Armand, A.D. (1986) Self-Development of the Systems. Institute of Geography of USSR AS Publishing, Moscow, 31 p.

[2] (1989) Ecosystems in Critical Situationd. Nauka, Moscow, 160 p.

[3] Rumyantsev, V.Yu., et al. (2013) Forecast of Probable Changes of Zonal Boundaries of Vegetation in European Russia and West Siberia Due to Warming. Siberian Ecological Journal, 20, 449-458. 
[4] Nazimova, D.I., Nozhenkova, L.E., Andreeva, N.M. and Polikarpov, N.P. (2002) Forecasts of Forest Cover Transformation in Siberia by Informational Bioclimatic Models. Siberian Ecological Journal, 4, 385-394.

[5] Bezdelova, A.P. (2006) Peculiarities of Zonal Situation of Trans-Baikal as Basis of Development of Steppe Advance in the Regional Vegetation Cover. In: Steppes of North Eurasia, Gazprom Publishers of Orengurggazprom Service Ltd., Orenburg, 99-102.

[6] Malyshev, Yu.S. (1998) Specifics of Ecological Approach and Some Problems of Assessment of Ecosystems Atate and Biodiversity Protection. In: Methods for Assessment of Ecosystems State, Nauka, Novosibirsk, 4-34.

[7] Holdridge, L.R. (1947) Determination of World Plant Formation from Simple Climate Data. Science, 105, $367-368$. http://dx.doi.org/10.1126/science.105.2727.367

[8] Berg, L.S. (1952) Geographical Zones of Soviet Union, Vol. 2. Geografgiz, Moscow, 510 p.

[9] Brown, J.H., Stevens, G.C. and Kaufman, D.M. (1996) The Geographic Range: Size, Shape, Boundaries, and Internal Structure. Annual Review of Ecology and Systematics, 27, 597-623. http://dx.doi.org/10.1146/annurev.ecolsys.27.1.597

[10] Chebakova, N.M., Reifeld, J. and Parfenova, Ye.I. (2003) Redistribution of Vegetation Zones and Populations of Siberian Larch and of Pine in Central Siberia at Climate Warming. Sib. Ecolog. Journ, 6, 677-686.

[11] Fonda, R.W. (1979) Ecology of Alpine Timberline in Olympic National Park. Proceeding of 1-st conf. sci. res, National Parks, New Orleans, Washington, Vol. 1, 209-212.

[12] Krauklis, A.A., Ed. (1991) Geosystems of Taiga and Steppes Contact: South of Central Siberia. Nauka, Novosibirsk, $216 \mathrm{p}$.

[13] Griggs, R.F. (1946) The Timberlines of Northern America and Their Interpretation. Ecology, 27, 275-289. http://dx.doi.org/10.2307/1933539

[14] Holtmeier, F.-K. (2009) Mountain Timberlines: Ecology, Patchiness and Dynamics. Springer, New York, 438 p.

[15] Korzhinsky, D.S. (1973) Theoretical Bases of Analysis of Minerals Parageneses. Nauka, Moscow, 288 p.

[16] Kullman, L. (1988) Holocene History of the Forest-Alpine Tundra Ecotones in the Scandes Mountains (Central Sweden). New Phytologist, 108, 101-110. http://dx.doi.org/10.1111/j.1469-8137.1988.tb00209.x

[17] Kullman, L. (2001) 20th century Climate Warming and Tree-Limit Rise in the Southern Scandes of Sweden. AMBIO, 30, 72-80. http://dx.doi.org/10.1579/0044-7447-30.2.72

[18] Lavrenko, Ye.M. (1980) Characteristics of Steppes as of Vegetation Type. Vegetation of USSR European Part, Nauka, Leningrad, 203-206.

[19] Mikheeva, A.I. (2011) Studies of Changes of Forest Upper Boundary Using Aero- and Space Photographs. Geodezia i Kartografia, 1, 31-36.

[20] Mil’kov, F.N. (1986) Physical Geography. About Landscape and Geographical Zonality. VSU Publishing House, Voronezh, $328 \mathrm{p}$.

[21] Neronov, V.V. (2008) Zonal Ecotones of North Eurasia: Investigation History and Structural-Functional Organization. Success of Modern Biology, 128, 35-51.

[22] Osipov, S.V. (2002) Notions "Plakor” and “Zonal Habitat” and Their Use While Revealing Zonal Vegetation and Zonal Ecosystems. Izvestiya RAN, 2, 59-65.

[23] Pears, N.V. (1968) Post-Glacial Tree-Lines of the Cairngorm Mountains, Scotland. Transactions of the Botanical Society of Edinburgh, 40, 361-394. http://dx.doi.org/10.1080/03746606808685163

[24] Rees, G., Tutubalina, O., Tommervik, H., Zimin, M., Mikheeva, A., Golubeva, E., et al. (2008) Mapping of the Eurasian Circumboreal Forest-Tundra Transition Zone by Remote Sensing. CBVM Meeting, Helsinki, 3-6 November 2008, 1-7.

[25] Reverdatto, V.V. (1947) Some Remarks in Insular Steppes in Siberia. Soviet Botany, 15, 364-365.

[26] Safronova, I.N. (2011) On Zonal Types and Zonal-Ecological Variations of Steppe Vegetation in the European Russia. Steppes Science Issues, IX, 141-143.

[27] Shiyatov, S.G. (1974) Some Data on Modern Trends in the Character of Forest and Tundra Relation in Pre-Polar Ural Mountains. Biological Problems of North, Yakutsk, No. 5, 90-94.

[28] Shiyatov, S.G. and Mazepa, V.S. (2015) Modern Invasion of Siberian Larch into Mountain Tundra of Polar Ural. Ecology, No. 6, 403-410.

[29] Tyulina, L.I. (1976) Humid Pre-Baikalian Type of Vegetation Belts. Nauka, Novosibirsk, 320 p.

[30] Vipper, P.B. (1963) Interaction of Forest and Steppe in the South-Western Part of Buryat Republic. Proceedings of Studies of Siberia and Far East Forests, Forest Institute of USSR AS SB Publishing House, Krasnoyarsk, 315-317.

[31] Walter, H. and Box, E. (1976) Global Classification of Natural Terrestrial Ecosystems. Vegetatio, 32, 75-81. http://dx.doi.org/10.1007/BF02111901 
[32] Weaver, J.E. and Clements, F.E. (1938) Plant Ecology. 2nd Edition, McGraw-Hill Book Co., New York, 601 p.

[33] Grigoryev, A.A. and Budyko, M.I. (1956) On Periodical Law of Geographic Zonality. Doklady Akademii Nauk SSSR, 110, $129-132$.

[34] Popov, M.G. (1953) On Relation of Forest (Taiga) and Steppe in Central Siberia. MOIP Bulletin, Biological Section, 58, 81-95.

[35] Yurtsev, B.A. (1974) Steppe Cenoses of Chukotka Tundra and Pleistocene “Tundra-Steppe”. Botanical Journal, 59, 484-501.

[36] Kakareka, S.V. (1994) On Forms of Forest and Steppe Contact in Tuva Republic. Geografia i Prirodnye Resursy, No. $1,62-69$

[37] Yermakov, N.B. (1986) Vegetation of the Area of Katun' Hydroelectric Power Plant Building. Geografia i Prirodnye Resursy, No. 4, 67-72.

[38] Ogureeva, G.N. (1999) Zones and Types of Belts of Russian Vegetation and of Adjacent Countries (Map. Scale 1:8,000,000). MSU Publishing House, Moscow, 2 Sheets.

[39] Lavrenko, Y.M. (1947) Principles and Units of Geobotanical Demarcation. USSR Geobotanical Demarcation. Leningrad, Moscow, 9-13.

[40] Safronova, I.N. (2012) On Problems of Zonal Subdivision of Arid Territory of Russian European Part. Botanical Journal, 97, 705-711.

[41] Vanderwel, M.C., Lyutsaev, V.S. and Purves, D.W. (2013) Climate-Related Variation in Mortality and Recruitment Determine Regional Forest-Type Distributions. Global Ecology and Biogeography, 22, 1192-1203. http://dx.doi.org/10.1111/geb.12081

[42] Dundin, Y.K. (1962) Natural Contacts of Forest and Steppe at the Extreme South-East of the USSR European Part. Moscow University News, Series 6, Biology, Soil Science, No. 4, 60-66.

[43] Voronkov, O.A., Tarasov, A.O. and Sukachev, V.S. (1993) Some Peculiarities of Forest Edges as Ecotones. Problems of Botanics in the Lower Volga, Saratov, 8-15.

[44] Clements, F.E. (1905) Research Methods in Ecology. Univ. Publ. Co., Lincoln Nebraska, 334 p.

[45] Clements, F.E. (1936) Natural and Structure of the Climax. Journal of Ecology, 24, 252-284. http://dx.doi.org/10.2307/2256278

[46] Krasovskaya, G.M. (2001) Ecotones as Indicators of the Dynamic of the High Range Geosistems. In: Ecotones in the Biosphere, Ecotones of Different Natural Zones, Nauka, Moscow, 90-95.

[47] Kravtsova, V.I. and Loshkareva, A.R. (2013) Dynamics of Vegetation of Tundra-Taiga Ecotone on Kola Peninsula Due to Climatic Oscillations. Ecology, No. 4, 275-283.

[48] Zaletaev, V.S. (2001) Ecotones Worldwide Network, Its Functions in the Biosphere and Role in the Global Changes. In: Ecotones in the Biosphere. Ecotones of Different Natural Zones, Nauka, Moscow, 77-89.

[49] Fersman, A.Y. (1937) Geochemistry. Vol. 3, Onty-khimteoret, Leningrad, 503 p.

[50] Grishankov, G.Y. (1977) Paragenetic Systems of Natural Zones (Illustrated by Crimea). Systematic Natural Research, Nauka, Moscow, 128-139.

[51] Ivanovsky, L.N. (2001) Paragenese and Paragenesis of Mountain Relief in the South of Siberia. Institute of Geography of RAS SB Publishing House, Irkutsk, 142 p.

[52] Krut', I.V. (1978) Introduction in the General Theory of Earth. Levels of Geosystems Organization. Mysl’, Moscow, $367 \mathrm{p}$.

[53] Kulikov, A.I., Bazhenov, V.S. and Ivanov, N.V. (2006) Soils Paragenesis and Paradynamics. BSC of RAS SB Publishing House, Ulan-Ude, 280 p.

[54] Mil’kov, F.N. (1966) Paragenetic Landscape Systems. Scientific Letters of the Voronezh Branch of USSR Geographical Society, Voronezh, 6-18.

[55] Reteyum, A.Y. (1972) On Paragenetic Landscape Systems. Izvestiya VGO, 104, 17-20.

[56] Shatsky, N.S. (1960) Parageneses of Sedimentary and Volcanic Rocks and Formations. Izvestiya Akademii Nauk SSSR. Geographical Series, No. 5, 3-23.

[57] Shvebs, G.I. (1981) Theoretical Basis of Erosions Science. Vishcha Shkola, Kiev, 222 p.

[58] Vasilyev, S.V. (2007) Paragenesis. Forest and Swamp Landscapes of West Siberia. Scientific and Technical Literature Publishing House of RAS SB, Tomsk, 24-29. 